\title{
The Contribution of College and University Libraries to the Training of the Armed Forces
}

The librarian of Riggs Memorial Library, Georgetown University, Washington, D.C., prepared this report at the request of the Association of College and Reference Libraries.

The Venerable PRACTICE of "taking $I_{\text {a survey" has always been attended }}$ by certain difficulties, not the least of which is the anxiety as to whether the data under review reveal facts of sufficient value to warrant the effort involved. In the present case this anxiety is happily absent, but its place has been filled by another and, perhaps, even more aggravating one. I refer to the speed with which the situation we shall discuss has changed and is changing.

The most important change took place after the questionnaire on which this article is based had been sent out. Those who have kept abreast of such matters will recall that the question of compensation to libraries for services rendered to trainees was for some time not very definite. Our questionnaire returns show that some college administrative officials did not ask the government for compensation for their libraries at all; in some cases compensation was given but the details were then considered confidential; in other cases compensation had not been given, and librarians were at a loss to know whether this was to be the permanent state of affairs or whether arrangements for payments would be made later on. Finally, some libraries reported hopefully that negotiations in which the interests of the library were being given attention were proceeding but had not yet been completed.

Vigorous representations on behalf of the libraries engaged in the various training programs were made to the Secretary of War by the American Library Association, based largely upon data supplied by Charles H. Brown, chairman of the Wartime Activities Committee, Association of College and Reference Libraries. Shortly thereafter the Secretary of War advised the A.L.A. that libraries were to receive compensation for work with trainees. The details of this compensation are embodied in the Army Service Forces Manual $M-102 .^{1}$

This Manual has been sent to the presidents of the colleges and universities engaged in training programs. It covers

1 Army Service Forces Manual M-102, Army Specialized Training Program, Training Unit Contract Instructions for University and College Authorities Offering Training Facilities for Army Trainees. Headquarters, Army Service Forces, Oct. 1, 1943. Approved by the Joint Army-Navy Board for Train. ing Unit Contracts, Sept. 9.' 1943, and Director 
expenses, use of facilities, instruction, medical services, subsistence, maintenance and operation, payments reports, revision of rates, and termination, and contains as appendices examples of a training unit contract and of revised working data forms. The Manual is designed, of course, to cover the entire plant and personnel of a given institution, the library being included as a part thereof.

The following is quoted from Section I I of Chapter 2, pages 22-23, of the Manual:

No allowance is provided in the use of facilities payment for the use of libraries as such. However, if certain rooms in library buildings are used for classrooms or study halls, then, of course, a payment should be calculated on the pro rata value of the space so used. All other use of the library facilities, however, when included in the contract will be paid for on the fee basis outlined under the instruction section of this manual. (See Chapter 3, paragraph I, h, (2).)

Elsewhere (paragraph I, h, (2) of Chapter 3, pages 34-35) the Manual reads:

\section{(2) Library Costs.}

Because of the inherent difficulties of proper valuation for libraries and because of the limited amount of use which the trainees in the program would make of the library service, it has been determined that the payment for the use of library facilities will be computed on a per capita fee basis only. In these cases the payment for library facilities is to represent a charge for library service only and is not intended to represent any allowance for so-called use of facilities for the library building or operation and maintenance of the library building. Reimbursement is intended to include only the direct cost of the library service itself. This should be computed on a per capita basis and included in the total instructional cost, Article 3 of the contract. For the occasional use of the library by the trainees, where its use is not required by the curriculum a charge not to exceed twenty-five cents per trainee per month may be included. However, where the curriculum specifies the use of the library, a satisfactory basis for arriving at the charge would be to ascertain the average cost of library service as shown by the financial reports of the institution for the past three years and then ascertain from the normal number of civilian students during that period what the per capita monthly charge would be. Whatever the calculation shows to be the proper normal cost of rendering library service may then be included, except that a maximum fee of one dollar per month per trainee is the limit which may be approved regardless of the normal library service cost. In this connection college officers should recognize that ordinarily it would be less expensive for the government to purchase necessary reference books and distribute them directly to the trainees than it would be to pay a greater charge for library service.

The matter of library compensation may be briefly summarized thus: one dollar per month per trainee is the maximum allowed when the library is definitely included in the curriculum (e.g., foreign area and language study). A maximum allowance of twenty-five cents per month per trainee is permitted when the use of the library is merely incidental to a given program. It should be noted that the survey we are discussing covers a number of "short-course" programs as well as the Army Specialized Training Program. The Manual mentioned above applies only to the A.S.T.P. and the Army Air Forces College Training Program. The A.S.T.P. should be distinguished from the other Army training programs included in the survey, such as judge advocate general, W.A.C., school for military government, meteorology, etc.

Librarians who may wish to have some suggestions as to the basis on which to calculate estimates of costs covering library 
service to military units are referred to the circulars on Libraries and the $W$ ar edited by Mr. Brown and available from the American Library Association.

One point cannot be stressed too much : all college and university librarians who are giving service of any kind to the armed forces are urgently requested to keep a record of such services in as much detail as circumstances permit and to send on promptly periodic summaries of facts and statistics to Charles H. Brown, Iowa State College Library, Ames. Such gains as the committee has been able to make are due in no little degree to the enterprise and initiative of those librarians who have kept Mr. Brown informed about what they are doing. If further gains are to be made, a steady flow of such information to the committee is essential.

The present article is based on a questionnaire sent out by the committee to 460 colleges and universities which are listed as being eligible for the assignment of military units. Not all of them, however, had such units assigned at the time of writing. Because staff shortages and lack of time are almost universal handicaps, the questionnaire was made as simple and as short as possible. It was agreed that the information submitted would be treated as confidential. For this reason the names of individual libraries and librarians have been omitted entirely throughout the present paper.

The points covered by the questionnaire are as follows:

I. What units of the Army, Navy, Air Force, or other branch are now at your college?

2. What is the approximate number of men in the armed forces receiving instruction from your faculty (Army, Navy, and Air Forces)?
3. What is the approximate number of men in the armed forces using the library per day (Army, Navy, and Air Forces)?

4. What provision is made for study rooms? 5. What provision has been made for recreation rooms, music, etc.?

6. Are lectures given by members of the library staff?

7. Add other notes which you think would be of value to us.

At the time of writing, 235 replies had been received from 44 states and the District of Columbia, the states not reporting being Delaware, Florida, Nevada, and Wyoming. A detailed statistical tabulation is given at the end of this article, the chief features of which we summarize here as follows:

A total of 524 training units were reported. Of these, 229 were Army units, I $70 \mathrm{Navy}$, and $125 \mathrm{Air}$ Forces. The total number of men and women receiving instruction is 186,479 , of which 81,397 classify under the Army, 65,107 under the Navy, and 39,975 under the Air Forces. The total number of trainees using the libraries of the reporting institutions per day is 52,383 , of which 24,036 are in the Army, 18,545 in the Navy, and 9802 in the Air Forces.

\section{Study Rooms}

Special provision for study rooms was made by 15 I libraries, while 84 reported that they did not make such provision. With the latter it was not a case of refusing cooperation but of local circumstances. The 84 libraries (with one exception) indicated that facilities for study were available elsewhere on the campuses. Sometimes libraries were turned over entirely to the use of trainees or to the combined use of trainees and civilian students. This latter arrangement was rendered pos- 
sible only because of the marked decrease in the regular student body. In the majority of cases the library's ordinary reading rooms were found to suffice, but not infrequently seminar, browsing, reserve book, and other rooms were placed at the disposal of the military authorities.

Library hours have been lengthened in many instances to care for servicemen. These changes range from an hour or so added at each end of the day to the opening up of additional rooms staffed for forty hours per week. Libraries which ordinarily close on Saturdays and Sundays have arranged to remain open on those days, and one New England library serves F.A.L.S. men I2 I hours per week. When the additional staff needed in order to lengthen hours cannot be obtained, some librarians have adopted the procedure of giving day service in the library with the understanding that the administrative officers of the college will provide quarters for evening study elsewhere on the campus. Such arrangements presuppose that the trainees bring their own books. In fact, the use of the reading rooms "for study purposes" generally has this connotation.

In addition to handling "mass formations" of the type just described, a number of libraries have personalized their service as an accommodation to individual trainees who have simply asked "for a place where I can study quietly." Even in cases where dormitories are furnished with lamps and reading tables, the noise and other distractions are so great that study is practically impossible. In one instance, stack cubicles were assigned upon request to senior class $\mathrm{V}-\mathrm{I} 2 \mathrm{men}$; in another, the men were given a general "stack privilege" (regardless of status) because this particular institution happened to have adequate means of supervision. A Massachusetts library placed sixty-one study tables in alcoves at the disposal of servicemen and reports that they are constantly in use by a Navy detachment. A District of Columbia library permits Army men to use desk space in the cataloging department. Numerous other instances of special accommodation might be cited.

Even in cases where dormitories have been equipped with reading and study rooms, these were often arranged and stocked with books by the library staff and thus became a part of the general library picture. One library reports that it supplied a room for the use of servicemen with "5500 pertinent books." When extra rooms were not readily available, the addition of a number of chairs in the existing rooms has helped to solve the problem. Another of the services reported was the installation of fluorescent lights for Army use. Only one library mentions, without further qualification, that there was "no available space in the library" for military students. In all cases but one the ordinary staff administered the reading rooms, the exceptional instance being that of an institution where "Navy personnel in charge of reading room after taps until I I P.M." was noted.

An example of study room and other library service closely resembling that given to trainees but directed not to the Army or Navy but to the training of civilian nurses was reported by a Pennsylvania librarian. The college in question is attended by eighty-three nurses who, although they have brought a number of books with them, are still provided with supplementary books and study room facilities by the library, even though the staff has been decreased and the number of users greatly increased. 


\section{Recreation Rooms}

As to the provision of recreation rooms, it is important in dealing with this type of library service to distinguish between the recreational use of the library's ordinary facilities and the use of recreation rooms as such. Otherwise one might easily give the impression that the library's resources have been dragooned into the service of amusement rather than of education properly so called. This is not, of course, to say that a library may not legitimately offer relaxation and light reading-some examples of this legitimate function of the library are given here, but the distinction should be kept clearly in mind to avoid misunderstanding.

The most frequent type of recreational service mentioned by the libraries surveyed is the "browsing room." Such rooms vary from a small, segregated collection of books in an alcove to large halls capable of seating a hundred or more persons and equipped with lounges, easy chairs, smoking stands, piano, radio, victrola, etc. Of the 235 reporting libraries, 48 offered such facilities and 187 did not, although a large proportion of the latter indicated that such facilities were available elsewhere on the campus.

Three libraries mentioned, as a part of their service, the use of art galleries. A Virginia librarian writes as follows:

Our museum was rented to the Navy in August 1942. Since then the library has sponsored a series of art exhibits available to the servicemen here and to those in nearby camps. This is a supplement to our regular program of activities but we do it so that art will not be entirely denied the people in our community while the war goes on.

When the library lacks a browsing room this service to the men has in numerous cases been supplied in cooperation with the military authorities by the establishment of such rooms in the barracks or in nearby dormitories. Thus a Colorado librarian writes: "The Navy Radio Unit and the Cooks and Bakers School do not use the library, but we established ward room libraries in their barracks which we service once a week." The same librarian also set up a library in sick bay on the campus and serviced this collection weekly.

Rental book collections are used to a considerable extent by members of the armed forces, although no statistics were assembled on this point. ${ }^{2}$

\section{Phonograph Use}

Victrola record collections proved to be the most popular form of nonbibliographical recreational service offered by libraries. Seven libraries reported the possession of the Carnegie "College Music Set" which covers the whole range of music throughout the centuries, and each of the seven librarians reported that the records received constant use by the trainees. Many other libraries have collections of records of varying sizes, and, although the general practice is to require that the records be played in the library's listening rooms, some grant permission to the men to borrow them. The use of listening rooms ranges from "a half hour each evening" (a West Virginia library) to "continuous use from 8:30 A.M. to 9:30 P.M." (a Georgia library). When the library itself does not maintain a record collection, the music department of the university is often mentioned as supplying this service. In one instance (an Alabama library) the music

2 "College Rental Libraries in the War Program," in The College Store, autumn r943, describes briefly the rental services at the universities of California and of Chicago. 
department transferred its entire collection to the library and set up three permanent listening rooms there. "At least one listening room has been in use by soldiers every hour the library is open. The music department holds weekly recorded concerts in the library."

Only one instance was mentioned of the use of a library's projection room and machine for motion pictures for the soldiers, and no library mentioned microfilm equipment under any head, recreational or otherwise. As for book displays, the returns show that although they are necessarily limited in comparison with peace times, they nevertheless form a definite part of library service to the trainees. The rare book collection proper, mentioned by just one library, was shown to be a means of arousing interest in the realm of books while offering at the same time a worth-while form of relaxation for men whose full schedules permit of very little time for anything except routine work.

\section{Library Lectures}

A unique opportunity has been offered by the present emergency for librarians to put into practice certain basic pedagogical principles which they have been urging for years. The ability to use the library intelligently is obviously essential to anyone who wishes to gain an education, and equally obvious is the fact that one means of gaining this ability in library use is instruction therein by persons technically qualified to give it. Many librarians have felt, and with good reason, that the arrival on their campuses of thousands of students ready to begin their college careers under military auspices presented the ideal condition for the realization of these principles on a large scale. Unfor- tunately, however, circumstances have combined, not to detract from the cogency of the principles, but to prevent librarians from actually demonstrating their validity.

A prime instance of this is the introductory library lecture. The returns from the libraries surveyed show that:

8 gave lectures to all students on the use of the library

5 gave such lectures to $\mathrm{Navy}$ students only

3 to R.O.T.C. students only

3 checked the entry but did not explain the type of lecture given

2 gave lectures to A.S.T.P. only

2 gave lectures to those taking the English course

I gave lectures to medical students only

I reported "four lectures given"

I reported "three lectures given"

I reported lectures "to all not previously in college"

I gave lectures on current best sellers (not on library use)

I reported lectures by library staff on nonlibrary subjects

I reported "staff available for lectures if needed"

I distributed a handbook explaining the use of the library

I reported lectures by members of the music staff

Why, it may be asked, out of all of the colleges whose libraries are handling servicemen, should such a paltry few report anything at all on such a vital function in the library's economy? The answer is brief: there is no time for such activity, and besides the trainees use textbooks. The latter point will be dealt with later. As for the first point, no phrase regarding library service is so frequently repeated as, "the men have no time." Librarians write that: "When the W.A.C. students finish a week's work, they want nothing 
but light reading;" "We offered our services, but the military officials said there was not time;" "The men on our campus have one hour at the end of the day to themselves, and we feel we would be imposing on them if we tried to make them use the library," etc. etc.

Meanwhile, what about the few libraries which did manage to furnish trainees with library instruction? We learn from a library in the East that the A.S.T.P. representative, as well as the dean of the school which handled a contingent of F.A.L.S. men, was heartily in favor of continuing the library lectures which had already been given successfully to several thousand S.T.A.R. troops. Yet the utter impossibility of working another hour into the schedule made impossible the continuance of a library training program which had proved its worth. However, the dean in question did incorporate the librarian's plan into his report to the Army officials, in order that the work of the library might receive proper attention.

Another library reported that the freshman English class was not only given instruction but was required to complete a certain number of problems in the use of reference tools. A librarian in New York State said that they had not given lectures but that so many questions were being asked about the use of the library by the cadets themselves that his staff had requested such lectures in order to lighten the work. The lectures were subsequently given to each incoming group of trainees.

In Colorado a librarian, in addition to addressing a general assembly of the A.S.T.U., gave them a short examination on their ability to use the library. This examination consists of four mimeographed pages and covers the use of the catalog, periodical indexes, standard refer- ence works, and library materials in special fields. It is an extremely interesting example of the type of test calculated not only to reveal the knowledge of the student but also to arouse his interest in reference work.

A significant contrast to the college noted above which reported a lecture on the library "to all not previously in college" is the comment from a librarian in the East. He writes:

After each lecture, in about three out of five cases, former college students came up to me and commented on how helpful it would have been to them had they had such an introduction to the library when they were in college. Even an elementary period in library use would have saved them lots of wasted time during their four years. I gave them the bleak consolation of telling them that specially conducted tests in library reference tools, given to graduate students, had proved that it was possible to pass through high school, college, and several years of graduate work without ever having heard of the Readers' Guide.

\section{Amount of Use}

As for the use that trainees make of the libraries of the institutions at which they are stationed, we have already noted that this was reported as being 52,383 per day. Thirteen libraries remarked that their collections received an extraordinary amount of use, while thirteen wrote that theirs received practically none. In many cases it seems that there was greater activity at the beginning of the training programs early in 1943 than was subsequently the case. Although the reasons for this have not been explicitly stated by every reporting library, the data at hand make it seem highly probable that the explanation lies in the fact that the S.T.A.R. programs, with which some libraries were then concerned, allowed the servicemen 
more time for study in the library. Moreover, the preparation for tests following the "refresher courses" tended far more to integrate the library with the curriculum than the later programs have.

As was to be expected, variation in the amount of use of the libraries reporting coincided to some extent with the different types of units being served. It would be a simple matter to report the precise situation in this regard if the correlation were constant, but it is not. One library writes, for example, that the Navy men use the library far more than the Army trainees. Yet another librarian indicates the exact opposite. One can only conclude that the pattern of use is determined locally.

However, two points stand out fairly definitely. First, the R.O.T.C. students use the library with greater freedom than any other group, for the obvious reason that their schedules approximate more nearly than those of any other group to the prewar balance between library and classroom. Second, the trainees, on the whole, make more use of the library when permitted to do so than civilian students. Here again the reason seems obvious: they have a more intense motivation than the average peacetime or civilian student. But it should be borne in mind that even here the reporting libraries were not unanimous on the superiority of military over civilian use: a large library in Iowa (to cite only one instance) adduced figures to demonstrate the contrary.

\section{Variation in Usage}

A specific example of this variation in usage among different units is afforded by a large Illinois library:

Heavy use of the library is made by the Civil Affairs Training School and the various programs in meteorology, for whom separate library provision has been made. The language and area units make less use of our Modern Language Reading Room. The Army Specialized Training Program makes little use of the library, except as a study hall and occasionally for recreational reading drawn from the college library.

Other letters could be quoted to illustrate emphases in other directions.

Of the libraries stressing the great amount of use given their collections by trainees, one reported sixty to seventy men per day, with the librarian busy with reference questions and reading guidance. A Colorado librarian says that "The men in our A.S.T.U. make great use of this library. By actual count, from 250 to 275 use the library daily. We have checked out 10,000 books for use in their barracks. Also, we do an appreciable amount of reference work." A New England librarian states that "Our campus has never been as busy as it is now. The library is crowded to the limit during study hours." From West Virginia comes a statement that "I have been surprised at the use of the library by the Army engineers. Many of them make serious and effective use of both our reading room and book collection."

Unfortunately, such extensive use of the library is not reflected in the majority of the institutions surveyed. Attendance figures are frequently quite high, but they are just that-"attendance" figures. They prove no more than that the library has afforded space for what is virtually nonlibrary work. Perhaps the most extreme case of nonuse comes from a New England institution:

A Naval program caused the cessation of all civilian programs. Navy supplies own faculty. ... Librarian granted leave of absence, library not in active use. ... Trainees do not use any of the institution's reference 
books ... though recreational use of magaines and browsing room proffered. But course is so intensive there is little time for reading.

A Pennsylvania library reports that, although there are $530 \mathrm{Navy}, \mathrm{Marine}$, and Air Force trainees on the campus, "not more than a dozen men use the library, and then it is for recreational reading." More deplorable yet is the situation of a librarian who wants to be of service but whose patrons (a Naval training contingent) are located ten miles away in a former C.C.C. camp.

\section{Influence of Textbooks}

The lack of time for either library training or library use has been commented upon. There remains another factor which is, perhaps, the most important of all. A Pennsylvania librarian placed his finger on it when he complained that the old textbook method was used rather than modern methods of instruction. Our survey reveals that in the majority of cases where the library has not been used, the textbook method of teaching has been a chief cause of this. There seems little doubt that the other important causelack of time-is intimately connected with the textbook factor, since this factor necessarily implies that consciousness of the library's function in education is absent. This being the case, it is natural that "little time" for its use would be provided in the schedule.

It is recognized by librarians, as well as by others, that in some subject fields, the library will naturally be called upon to play a role of less importance than in others. Physics, mathematics, and biology students, for example, while they cannot afford to ignore the library, nevertheless do not ordinarily make the same demands upon it as do students of economics, English, geography, and history.

However, the most interesting development regarding this general problem has been the way in which the textbook method has proved self-refuting. Time and again the military authorities are quoted as maintaining that "the use of the library will not be necessary because we're using textbooks." Now it is quite true that a heavy schedule and an intense concentration on a single textbook are bound to reduce seriously the use of the library, and have indeed done so. But-and this is the point-despite this obstacle a number of librarians report that individual students are continually coming into the library and using it anyway. But how, it may be asked, when the lack of time has been demonstrated, can this be true? The answer is that the men simply make their own opportunities. They come in during meal times or snatch odd minutes between classes or even use the one precious hour during the day which they have to themselves. In one way or another, they unconsciously demonstrate that the textbook alone is not enough. Most modern educators, and certainly most librarians, were of this opinion in the first place, but we repeat that this empirical substantiation of the fact, coming from the rank and file of the students themselves, merits attention.

An ironic incident is reported by the librarian of a large university in the East. The military authorities had maintained that the library would not be needed by the trainees. One of these officers attempted several times to reach the librarian on the telephone and complained later to the librarian that he had been told "to call back" each time. He wanted to know why. It turned out that the librarian 
was so busy giving reference service in the reading room to the trainees "who do not need to use the library" that he hadn't had time to come to the telephone.

\section{Book Purchases}

The selection and purchase of books for trainees have been reported by the libraries surveyed to lie chiefly in the following subject fields: aeronautics, chemistry, codes and ciphers, economics, engineering, first aid, geography, history, mathematics, medicine and dentistry, meteorology, military science, physics, war books (current), and foreign languages.

The following excerpts from the letters received may stand as representative of what many librarians are doing for trainees in the matter of book purchases: "We have added about 3000 new books to our collection in both U.S. history and economic geography; also the newest war books and the older American history and American literature [titles] are in constant demand" (Colorado); "Purchase of many expensive, valuable background naval history books. These are popular with seamen and are needed for naval history course" (Michigan) ; "We have developed a basic collection in meteorology for the use of the Army and are continuing to add to it the more significant current titles and government publications" (District of Columbia); "Our book buying has been predominantly in fiction and war books" (Vermont); "We have bought for the servicemen books on strategy, tactics, and the progress of various campaigns" (Texas).

In many instances duplicate periodical and newspaper subscriptions have been taken for the benefit of trainees and duplicate copies purchased of those books in various fields which have received the greatest use. An Illinois library which serves 250 military students orders all of the textbooks used by them. Since each man uses a dozen different texts, this one service alone entailed the handling of three thousand individual books.

\section{Circulation}

It is the almost universal practice among the reporting libraries to extend borrowing privileges to the service men and women on their campuses on the same basis on which the regular student body is served. In fact, a few libraries went so far as to dispense with the ordinary circulation machinery and allow the trainees to borrow books by simply signing a slip for them. The reasons given for this practice were that diminished staff and increased patronage left no alternative in the matter, that there was very little danger of book losses because the borrowers in these cases were living in a restricted area, and that the libraries concerned were in direct touch with the military officers, to whom delinquents could be immediately reported. There may have been isolated cases in which this privilege was abused, but not a single one was mentioned by any of the libraries surveyed. This experience bears out the impression of many librarians that the service men and women, in their appreciation of library service, are somewhat above the average.

There have been widespread efforts to encourage the circulation of books among military students. An Iowa library writes that in addition to the usual new-book shelf, they laid particular stress on the hobbies in which their patrons were interested. The same point was emphasized by a District of Columbia library, which guided its selection of popular reading by announcing to assemblies of servicemen 
that they might leave at the charge desk requests for the books they desired. Such books, upon accessioning, were held at the reserve desk and the requestants notified of their arrival. Individual services of this type are a potent influence in awakening library users to the benefits that a library can offer. It should be noted that a number of libraries mentioned that they made their services available not only to the trainees proper but to the officers and their families stationed on or near the campuses.

An interesting statistical check was made by a Virginia librarian. On September 28 a survey of $\mathrm{V}-\mathrm{I} 2$ and civilian borrowers was made by examining the charge file. This showed that 442 volumes were in circulation: 150 books were charged out to 80 trainees and 292 volumes to "others" (i.e., civilians and offcampus patrons). In other words, 34 per cent of the books circulated had been borrowed by trainees, and these trainees constituted 15 per cent of the total number enrolled in the college. Over a six-day period, it was found that one third of the enlisted men had books out from the library's shelves.

A Kentucky library writes that borrowers' cards were issued to I44 out of 300 Navy men; a Connecticut institution mentions that a purely voluntary borrowing privilege was taken advantage of by 6 officers and 57 cadets who, at the time of writing, had charged out from 2 to 37 books each; a Pennsylvania library listed I2I trainees registered as borrowers. From Alabama comes word that "a great many books are circulated to soldiers, especially in the S.T.A.R. unit. These charges total from 9 to 173 per day, making a daily average of I16." An Arkansas librarian notes that 18 to 20 per cent of the books in circulation were taken out by trainees. Over a thirty-day period there was a circulation of 4363 books, of which 857 or 19.6 per cent went to trainees. According to an Oregon librarian, 40.7 per cent of the reserve circulation and 25 per cent of the general circulation during August were accounted for by A.S.T.P. students. An Arkansas library, in reporting for the month of September, noted that 765 books, or 31 per cent of their "two weeks" charges, were out to Army men. In addition to this, approximately 90 volumes per day were applied for and used in the reading room but not charged out.

It should be remembered that these services are being extended by libraries whose staff strength has been, in every case, more or less seriously diminished by war conditions. When this is kept in mind, the report from a Kansas library (typical of many) that the "loan department estimates that it devotes as much as 40 per cent of its attention to servicemen" may be seen in its proper perspective. The same institution writes that its reference department receives the same number of requests for information from servicemen as from civilians. The periodicals department frequently gives 100 per cent of its time, while the reserve book room serves an average of one hundred trainees daily.

An interesting example of how the circulation of books to soldiers can serve as a means of cementing library-faculty relationships is given by a Pennsylvania library. The books being circulated to trainees at this institution revealed an interest in history. A member of the history faculty gathered together a number of servicemen from his classes who were interested enough in the historical issues behind the present war to devote the little 
spare time at their disposal to outside reading and discussion. In cooperation with the library these trainees received individual bibliographical service, and the response of the men was such that the teacher in question declared the sessions to be at times "the equivalent of graduate seminars, with an enthusiasm often lacking in regular college work." An activity of this sort, carried out under the most difficult conditions (the schedules of all the participants were already heavy) serves as an instructive footnote on the whole question of textbook versus personalized methods in teaching.

\section{Reserve Shelves}

A customary practice among the greater number of the libraries surveyed is the establishment of reserved-book shelves devised specifically to meet various needs of the military units stationed on the campuses. Sixteen of the reporting libraries made particularly detailed mention of this aspect of their service. The reserve collections have not been confined to books alone. Typical of many reports is that of a Massachusetts college which writes that "We keep weather maps, topographic maps, mosaics, and aerial photographs" in the reading room for the use of trainees.

A large library in Iowa mentions a reserve collection of "several hundred books for the use of F.A.L.S. students," and a library in Nebraska has equipped every classroom in the building with a collection of relevant materials. This phase of library activity reflects once more the need to supplement classroom work with library service. An Arkansas librarian devised his reserve shelves after a careful examination of the textbooks used, so as to be sure that the students would have an opportunity to consult more than one classroom text on each phase of the subjects being studied. In each case reported, the use which such collections receive has demonstrated their necessity.

Typical of the libraries which have gone beyond the strictly routine procedures in library service is a Massachusetts institution:

As Navy students are taking their regular academic courses, their use of the library extends to all classifications.... As all seniors are to present theses as partial requirement for their degrees, this entails considerable reference work on the part of the library staff in assisting students in the choice of books, checking references, securing periodical material, and compiling bibliographies.

Reserve shelves and tables frequently carry also periodicals subscribed to for the benefit of trainees. An Iowa library, for instance, has added thirty-three periodical subscriptions to its regular list for this purpose. War information files, while not assembled or maintained primarily for servicemen, are nevertheless among the reserved materials available to them. Faculty members assist in many instances in the formation of reserve collections, and a small proportion of the reporting librarians state that members of the teaching staff serve as consultants for the library in their special fields.

\section{Compensation}

The question of compensation has already been treated, but the returned questionnaires contain some further facts which may be of interest to librarians. Partial compensation is sometimes given in nonmonetary form, as when a library is supplied with books by the government authorities. "Sets of dictionaries were issued to us by the Navy," writes one librarian, "for the use of Navy men in 
their translation work." In another case the Army made a similar arrangement. Sometimes the library accessions and catalogs the books, while in one case "the Navy bought eighty copies of two different books on naval science which the library handles as reserves but which are not accessioned or cataloged." Books supplied by the government, although usually reported as being used for the courses taught, are not necessarily so used. A librarian writes that his library "has received from the Navy one thousand volumes of recreational reading material. These are cataloged as a regular part of our collection."

Now and then the delay in payment for library service has caused local complications. A librarian reports:

The commanding officer declared the library to be "out-of-bounds" for students in the A.S.T.P. and A.S.T.R.P., basing his reason on the fact that the Army was making no provision for library service. It took a week to get this order repealed, and since these boys were the ones that borrowed the most books, because they have more free time than the air crew, it had a decided effect upon the circulation. It took a letter from the president of the university to change the order, based on the reasoning that our library was open to the public and moreover the university did not want to deprive the cadets of university facilities that were available for use, even though they were not being recompensed for wear and tear for their use.

\section{Attitude of Military Officials}

Since librarians have endeavored for years to educate educators to the importance of libraries and their function in the college economy, it should not come as a surprise that, to a certain extent at least, it is necessary to elucidate these things to the military authorities who, in some cases, are dealing for the first time with libraries as administrative units. The great ma- jority of librarians who adverted to the point in the questionnaires wrote that the attitude of the military officers was that if textbooks are used libraries are not necessary. At the same time, the returns show that while this is generally the initial attitude, it tends to change as time goes on and the role played by the library becomes clearer to the officers in charge.

There are indications that the military authorities are ready enough to incorporate the library explicitly into the training programs if only they are shown the facts. A major in charge of Army training in a certain area interviewed the librarian of a college which was to receive trainees. They discussed the situation at length, and when the major left he said that he wanted the soldiers instructed in the rapid use of technical periodical literature and in reference work. In this case there was opportunity for the librarian to present directly and clearly what it was that he had to offer. Too often, our questionnaire reveals, decisions involving the library have been made without consulting the librarian at all.

Quite recently the A.S.T.P. representative of a university posted a notice in the faculty reading room, stating that he had received a letter from a high ranking officer in the A.S.T.P. asking for the comments and reactions of the teachers on the progress of the training programs in that institution. The librarian immediately availed himself of this opportunity offered by the Army to state his case. It is too soon to tell what effect his letter had, but the important point is the open-minded attitude on the part of the general who wrote the letter.

The questionnaires returned leave no doubt that the attitude of the military authorities toward the library is still in 
process of formation and that the extent to which further recognition of library service is extended to colleges and universities will depend in large measure on the energy with which librarians continue to render service and to keep the proper quarters informed about these services.

\section{Statistical Tabulation}

Number of questionnaires sent : 460

Number of replies received: 235

Number of states represented: 44 (and the District of Columbia)

Approximate number of men in the armed forces receiving instruction:

Army ................ 81,397

Navy ................ 65,107

Air Force .............. 39,975

Total . 186,479

Approximate number of men in the armed forces using the library per day:

Army ................ 24,036

Navy ............... I 8,545

Air Force $\ldots \ldots \ldots \ldots \ldots \ldots, 9,802$

Total 52,383

A list of the type and number of units as reported:

a. Army

98 A.S.T.P. units

63 R.O.T.C.

I6 S.T.A.R.

15 A.S.T.R.P.

6 Medical Schools

6 F.A.L.S.

6 S.O.A.

2 Signal Schools

2 W.A.C.

2 A.A.S.

I Dental School

I Fiscal School

I Auto Mechanics School

I Civil Affairs Training School

I Electronics School

I Graduate Engineers

I J.A.G.

I Meteorologists

I Nurses School

I Q.M.C.
I Q.M. Petroleum School

I School of Military Government

I U.S. Military Academy

229 total number of Army units

b. Navy

$93 \mathrm{~V}-12$ units

21 N.R.O.T.C.

15 N.T.S.

7 Medical Schools

7 W.A.V.E.

5 M.C.W.R.

4 Marines

3 S.P.A.R.

2 Diesel Schools

2 Midshipman's Schools

2 Radio Schools

I Chaplain's unit

I International Administration

I Meteorology

I Accounting School

I Dental School

I Supply

I Electronics

I Recognition

I Signal School

I 70 total number of Navy units

c. Air Force

29 C.A.A.-W.T.S. units

23 Preflight A.S.

20 College Detachment Air Crew

20 F.P.S.

9 A.A.F.-T.T.C. (premeteorology)

8 C.A.A.-W.T.S. (Naval)

3 Air Crew Program

3 Preflight A.S. (Naval)

2 Army Air Forces (Air Crew Training Unit)

2 Army Air Forces (College Training Program)

2 Meteorology

I Air Corps Statistical School

I F.P.S. (Naval)

I U.S. Cadet Nurses Training Corps

I Weather Training Command, Class C, Premeteorology Group

I25 total number of Air Force units

Combined total of Army, Navy, and Air Force units: 524 . 


\section{Aid for Libraries Serving A.S.T.P.}

\section{To Secretary Henry L. Stimson:}

The American Library Association has been informed that Army officers negotiating contracts with colleges in connection with the Army Specialized Training Program are forbidden to permit the inclusion of any allowance for the use of the library in these contracts except in the case of language instruction. The Association has also been informed that tentative contracts already drawn up for the inclusion of such an allowance have been cancelled by orders from Washington. The Association hopes that these reports are incorrect. We are writing to you, therefore, asking that you inform us of the actual status.

If our information is correct, the American Library Association respectfully calls to your attention the following facts:

I. Modern methods of instruction in colleges and universities in general require the use of a large number of books rather than the use of a single textbook. These methods have been generally approved by educators and faculty members throughout the country. It has been found desirable to familiarize students with the work of outstanding authors and to instill in them the habit of consulting a number of books and investigating sources for themselves.

2. While these methods are considered of especial importance in practically all courses of history and English, they are also used in other courses. For example, engineering students are expected to be familiar with the current engineering magazines and should be able to look up material for themselves in these magazines. The modern engineer must familiarize himself with the latest engineering methods if he is to perform his duties satisfactorily.

3. The Army and Navy have recognized the importance of this principle. Excellent libraries have been established in camps and training stations both here and abroad and on board ship. Libraries have been organized on military stations throughout the country. In connection with the training overseas, a large collection of books has been sent abroad. The service of a professional librarian has been requested by the commander of the forces in North Africa. There seems to be an apparent inconsistency in furnishing libraries and library service to military units in this country and abroad and in denying such service to units in training in this country just at the time when the use of a considerable number of books and magazines would seem to be most valuable to them.

4. Although the Army Specialized Training Program has been in operation only a short time, reports from libraries indicate a very considerable use of library books by enlisted men. A librarian in the Middle Atlantic states reports that sixty of the soldiers borrowed several hundred books during their stay. (S.T.A.R. Unit.) The adjutant has expressed his satisfaction with the work of the library because, he says, it is the library and its books that influence a soldier, more than any other factor, to continue with his college course. Several libraries have reported an unprecedented demand for mathematical texts by enlisted men who desired to review their high school and firstyear mathematics. One institution added fifty books for this purpose and still could not satisfy the demands.

A library in the Rocky Mountain region reports that a unit of 250 men was studying in the library daily and that the use of books by these men was equal to that of the same number of civilian students. An institution in the South kept statistics of the use of its library by enlisted men. The librarian reports that the use by enlisted men is in excess of the use by the same number of civilians. Another technical institution in the South reports that one third of the enlisted men on the campus use the library daily by actual count.

Another librarian reports that the demands from enlisted men for books were so great that a total of 1136 books were borrowed from faculty members for the use of enlisted men. Six thousand one hundred and fourteen volumes were called for by enlisted men at the main circulation desk during the month of June. 
If no allowance is made for the use of the library for men engaged in the various training programs in a college, the college will be obliged to choose between:

a. Abandonment of methods of instruction generally approved by educators of the country ; or,

b. Payment of expenses of approved and desirable methods of instruction from its own funds.

Althea H. Warren

A.L.A. President

Carl H. Milam

A.L.A. Executive Secretary

\section{To Althea H. Warren:}

Further reference is made to your letter of August 31, I943, regarding the use of college libraries in connection with the Army Specialized Training Program.
You will be pleased to learn that at a recent meeting of the Joint Army-Navy Board for Training Unit Contracts a policy was adopted whereby an institution being used in the Army Specialized Training Program will receive compensation for the use of its library. It should be pointed out, however, that the War Department has always allowed a library fee in the foreign area and language curricula of the Army Specialized Training Program.

Instructions on the proper contract procedure have been forwarded to all service commands and future contracts will reflect the new policy.

I assure you that your interest in this matter is appreciated by the War Department.

Henry L. Stimson Secretary of $W$ ar 